\title{
Detection and Molecular Characterization of Benzimidazole Resistance Among Colletotrichum truncatum Isolates Infecting Bell Pepper in Trinidad
}

\author{
H. Ramdial, F. N. Hosein, and S. N. Rampersad, The University of the West Indies, Faculty of Science and Technology, Department of Life \\ Sciences, St. Augustine, Trinidad and Tobago, West Indies
}

\begin{abstract}
Ramdial, H., Hosein, F. N., and Rampersad, S. N. 2016. Detection and molecular characterization of benzimidazole resistance among Colletotrichum truncatum isolates infecting bell pepper in Trinidad. Plant Dis. 100:1146-1152.

Anthracnose is an economically important disease that affects pepper (Capsicum spp.) production worldwide. Eighty-seven Colletotrichum truncatum isolates infecting bell pepper in Trinidad were isolated and screened for resistance to benomyl. All isolates were found to be highly resistant at the discriminatory dose of $10.0 \mu \mathrm{g} / \mathrm{ml}$. The effective concentration required to achieve $50 \%$ colony growth inhibition values were found to be significantly higher $(P \leq 0.05)$ for isolates collected in South Trinidad compared with those collected in North Trinidad. Isolates with the resistant phenotype had a single amino acid substitution from glutamic acid to alanine at position 198 (E198A) within the $\beta$-tubulin 2 gene. Single-nucleotide polymorphisms that result in amino acid substitutions in the $\beta$-tubulin 2 protein are associated with high resistance to benzimidazole chemistries. There were also two other deduced amino acid changes at nucleotide positions 359 to 361 (ATA/TTG [F270Y]) and

at 362 to $364(\mathrm{CGC} / \mathrm{GCC}$ [A271S]). Genetic analysis revealed that benomyl-sensitive isolates clustered separately from the resistant isolates regardless of species, with strong bootstrap support (85\%). Within the resistance cluster, there was an apparent differentiation among those isolates with the F200Y, E198A, and E198K genotypes, with moderate support ( $>60 \%$ ) for clustering of the F200Y and E198K genotypes. C. truncatum clustered separately (97\%) from the other resistant genotypes due to the additional amino acid substitutions detected. The findings also indicated that consistent benzimidazole fungicide use may explain the predominance of the $C$. truncatum pathogen populations in bell pepper fields in Trinidad because sensitive $C$. gloeosporioides sensu lato isolates were selectively minimized. This underlines the importance of accurate identification of Colletotrichum spp. associated with anthracnose disease and routine monitoring for development of fungicide resistance.
\end{abstract}

Anthracnose is among the most economically important diseases affecting pepper (Capsicum spp.) production in the tropics and subtropics (Than et al. 2008). Infection occurs as a pre- and postharvest fruit rot which reduces marketable yield and results in considerable economic losses. At least four species of Colletotrichum-Colletotrichum truncatum (syn. C. capsici) (Damm et al. 2009), C. gloeosporioides, $C$. coccodes, and $C$. acutatum - have been implicated as important pathogens causing pepper anthracnose, with $C$. truncatum being the most destructive (Montri et al. 2009; Sharma et al. 2005).

Fruit symptoms include water-soaked, circular or angular sunken lesions that can develop as a single large lesion or as multiple smaller lesions covering most of the fruit. Concentric rings of acervuli may also develop within the lesions, ranging from brown to black in color as setae and sclerotia develop (Roberts et al. 2001), with pink to orange conidial masses (Than et al. 2008). In severe infections, lesions may coalesce and cause fruit discoloration (Roberts et al. 2001). There is a distinction between anthracnose on immature fruit caused by $C$. acutatum, which has been termed "early anthracnose", and disease caused by $C$. gloeosporioides sensu lato on mature red fruit (Harp et al. 2014, 2008; Lewis Ivey et al. 2004).

Although anthracnose affects all aboveground parts of the plant during any growth stage, fruit lesions are primarily responsible for reducing marketable yield. These pathogens may also persist for a long period of time on alternate hosts such as other solanaceous crops and weeds. Colletotrichum spp. can survive and be disseminated in a variety of ways in and on seed as acervuli and microsclerotia (Pernezny et al. 2003), as well as in diseased fruit, which can act as a source of inoculum via water splash or irrigation water (Roberts

Corresponding author: S. N. Rampersad;

E-mail: sephra.rampersad@sta.uwi.edu

Accepted for publication 23 January 2016.

http://dx.doi.org/10.1094/PDIS-09-15-0995-RE

(c) 2016 The American Phytopathological Society et al. 2001). The fungus can also overwinter on alternative hosts by producing microsclerotia (Pring et al. 1995).

Management of anthracnose should include integrated cultural, biological, and chemical control strategies. Currently, there are no known bell pepper cultivars that are resistant to anthracnose fruit rot. Use of pathogen-free planting material, proper field drainage, and removal of infected debris from previously infected crops and weeds are important cultural means of reducing disease losses. Rotation out of susceptible solanaceous crops for a minimum of 2 years is also advised (Roberts et al. 2001). Wounding of the fruit by insect feeding must also be minimized because breaks in the cuticle may allow fungal entry and establishment (AVRDC 1991, 2004; Conn 2006; Pernezny et al. 2003).

The benzimidazole or methyl benzimidazole carbamate fungicides are single-site inhibitors that disrupt $\beta$-tubulin polymerization in many species of fungi. They appear to disrupt the cytoskeleton (Davidse 1986; Wade 2007) and cause abnormal spore germination and germ tube elongation, and negatively affect growth of sensitive fungi (Fungicide Resistance Action Committee group 1) (FRAC 2015). The target protein is encoded by the $\beta$-tubulin 2 gene (Morton and Staub 2008). As a consequence, sensitivity to inhibitors is highly variable (FRAC 2015). By 1984, there were reports of resistance among a diverse range of plant pathogen populations (Smith 1988). According to Lucas et al. (2015), resistance can arise after only 2 years of continuous use of benzimidazoles and represents a timeline to resistance that is similar for quinone outside inhibitors, 2-aminopyrimidines, and phenylamides.

Some fungal taxa are naturally insensitive to a specific chemical group, which means that fungicides, therefore, should manifest a spectrum of inhibitory effects in sensitive fungi (i.e., highly sensitive to highly resistant); molecular variation in the target site is one likely explanation for intrinsic resistance (Lucas et al. 2015). Alternatively, there may be redundancy in the protein target due to the presence of additional copies of the encoding gene. For such a conserved protein, there will be functional constraints in addition to complex pleiotropic and epistatic effects; yet, in spite of this, various mutations have emerged in different plant-pathogenic fungi in the field (Lucas 
et al. 2015; Ma and Michailides 2005). It has recently been found that Fusarium graminearum has two $\beta$-tubulins (Liu et al. 2013), with resistance being conferred by mutations in one of the two. Of these mutations, amino acid substitutions in the $\beta$-tubulin 2 protein are associated with high resistance to benzimidazole chemistries following sustained field applications. At amino acid position 198, alanine (Ala), glycine, or lysine is exchanged for glutamic acid (Glu); or, at amino acid position 200, tyrosine is exchanged for phenylalanine (Lucas et al. 2015). The mutation results in a loss or reduction of the binding affinity to benzimidazoles (Davidse 1986; Ma and Michailides 2005; Steffens et al. 1996).

The E198A genotype has been identified in resistant isolates of Colletotrichum spp. associated with postbloom fruit drop disease of citrus in the United States and Brazil (Peres et al. 2004), various fruit crops in Japan (Chung et al. 2006), Limonium spp. in Israel (Maymon et al. 2006), and turf grass and creeping bent grass (Wong et al. 2008; Young et al. 2010) and, recently, fruit rot of peach and blueberry in the United States (Hu et al. 2015). Point mutations in the $\beta$-tubulin gene have also been detected in several other phytopathogenic fungi, including but not limited to Monilinia fructicola (Ma et al. 2003), Botrytis cinerea (Yarden and Katan 1993; Zhang et al. 2010), Aspergillus nidulans (Jung and Oakley 1990), Penicillium digitatum (Schmidt et al. 2006), Cercospora beticola (Davidson et al. 2006), Gibberella zeae (Liu et al. 2010), and Venturia inaequalis (Koenraadt et al. 1992). Overall, mutations at position 198 were most common in resistant field isolates, suggesting that this point mutation does not significantly affect the correct functioning of the $\beta$-tubulin 2 protein, resulting in a concomitant loss of fitness in these isolates (Lucas et al. 2015).

In Trinidad, bell pepper cultivation takes place year-round, with peak production occurring from July to November (Mohammed 2013), which coincides with the rainy season. Growers do not practice crop rotation and generally irrigate using furrow irrigation. Between 2006 and 2010, there was a decline in export of bell pepper from Trinidad to Barbados and Canada (136 tons in 2010 compared with 202 tons in 2006) (Mohammed 2013). Conversely, importation of bell pepper from the United States to Trinidad increased from 62 tons in 2006 to 202 tons in 2010 (Mohammed 2013). One explanation for importation of bell pepper is the relatively high production cost faced by local growers and the yield losses incurred due to disease. Growers are reliant on chemical control of anthracnose. In a countrywide survey conducted in 2013 , it was found that over $80 \%$ of all growers utilize benzimidazole fungicides in an attempt to sustain year-round bell pepper production. Prior to 2010, benomyl was a popular fungicide used by most growers but, more recently, carbendazim was among the top-selling fungicides; both are benzimidazole fungicides with the same mode of action (personal communication with the owner of a leading supply company in North Trinidad called ASASCO).

In a 2009 survey of bell pepper fields located in North Trinidad (Aranguez region), of the 32 isolates collected, $72 \%$ were identified as Colletotrichum truncatum and $28 \%$ were identified as C. gloeosporioides sensu lato (Ramdial and Rampersad 2014). In 2013, however, the same five fields were resampled and it was found that $91 \%$ of all Colletotrichum isolates $(n=31)$ were C. truncatum and only $9 \%$ were $C$. gloeosporioides sensu lato.
Within a time frame of 4 years, there was an apparent shift in the populations of $C$. gloeosporioides sensu lato and $C$. truncatum isolates infecting bell pepper in those fields. Importantly, the sampling times (i.e., the rainy season from September to December), the cultivars grown, the chemicals used, and the five fields sampled in 2009 and again in 2013 were all consistent. During this 4-year period, there was no crop rotation or change in chemical use. Therefore, sampling bias was discounted. In 2009, C. gloeosporioides sensu lato isolates were found to be sensitive to benomyl at $10 \mu \mathrm{g} / \mathrm{ml}$; the only resistant Colletotrichum isolates detected were $C$. truncatum (Ramdial and Rampersad 2014).

Fungicide use can influence the dynamics and abundance of pathogen populations and result in selection of resistant populations. Such populations may persist in fields even after withdrawal of the chemical, depending on the stability of the trait and the fitness of resistant strains (Lucas et al. 2015). It is hypothesized that consistent benzimidazole fungicide use may explain the predominance of the C. truncatum pathogen populations in bell pepper fields in Trinidad because sensitive $C$. gloeosporioides sensu lato isolates were selectively minimized. The predominance of $C$. truncatum isolates in bell pepper fields in Trinidad also suggests that this species may be highly resistant to benzimidazole fungicides. Rampersad (2011) reported that $C$. truncatum isolates infecting papaya (Carica papaya L.) in Trinidad were highly resistant (effective concentration required to achieve $50 \%$ colony growth inhibition $\left[\mathrm{EC}_{50}\right]>1,000.0 \mu \mathrm{g} / \mathrm{ml}$ ) to benomyl.

Based on the frequency of use of benomyl to control anthracnose fruit rot in bell pepper in Trinidad and the potential for $\mathrm{Col}$ letotrichum isolates to develop resistance, a study was done to investigate the occurrence and genetic basis of resistant and sensitive C. truncatum isolates. The specific objectives included (i) an evaluation of $C$. truncatum isolates for resistance to benomyl fungicide based on in vitro bioassays and (ii) comparative analysis of the nucleotide sequences of the $\beta$-tubulin 2 gene to detect amino acid changes that are associated with the resistant phenotype.

\section{Materials and Methods}

Isolate collection. Seventeen fields were sampled for anthracnose fruit rot infection in the major production areas in Trinidad (Table 1). Symptomatic fruit with diagnostic symptoms were collected (Fig. 1) and surface disinfested by rinsing in $70 \%$ ethanol for $1 \mathrm{~min}$, followed by another rinse in $0.6 \%$ sodium hypochlorite solution for $1 \mathrm{~min}$. Samples were then washed three times in sterilized distilled water and dried on sterilized tissue paper in a laminar flow hood. A 4$\mathrm{mm}^{3}$ block of tissue was cut from the edge of the lesion and placed at center of streptomycin-tetracycline-ethanol agar (STEA) plates ( $2 \%$ water agar amended with streptomycin at $50 \mathrm{mg} / \mathrm{liter}$, tetracycline at $50 \mathrm{mg} /$ liter [Sigma-Aldrich], and $5 \%$ absolute ethanol). STEA plates were incubated for 5 days at $25^{\circ} \mathrm{C}$ in the dark. After incubation, a 4- $\mathrm{mm}^{3}$ block of agar taken from the advancing mycelial edge of a 5-day-old STEA culture was removed and placed in the center of potato dextrose agar (PDA) plate (Oxoid Ltd.) supplemented with streptomycin at $50 \mathrm{mg} / \mathrm{liter}$ and tetracycline at $50 \mathrm{mg} / \mathrm{liter}$. Cultures were incubated for 7 days at $25^{\circ} \mathrm{C}$ in the dark. Monoconidial cultures $(n=97)$ were subsequently obtained through serial dilution. Isolates were maintained on PDA slants at $4{ }^{\circ} \mathrm{C}$ for temporary

Table 1. Colletotrichum isolates collected in 2013 from bell pepper fields in Trinidad

\begin{tabular}{|c|c|c|c|c|c|c|}
\hline Field location & District & Population code & Cultivars grown & $\begin{array}{c}\text { Total number } \\
\text { of isolates }\end{array}$ & $\begin{array}{l}\text { Number of Colletotrichum } \\
\text { gloeosporioides sensu } \\
\text { lato isolates }\end{array}$ & $\begin{array}{c}\text { Number of } \\
\text { C. truncatum isolates }\end{array}$ \\
\hline Aranguez (5 fields) & St. George East & A1-A5 & $\begin{array}{l}\text { Aristotle, Anaconda, } \\
\text { Canape }\end{array}$ & 31 & 3 & 28 \\
\hline $\begin{array}{l}\text { Maloney ( } 3 \text { fields) and } \\
\text { Macoya ( } 3 \text { fields) }\end{array}$ & St. George East & M1-M2 & $\begin{array}{l}\text { Aristotle, Anaconda, } \\
\text { Canape }\end{array}$ & 29 & 2 & 27 \\
\hline $\begin{array}{l}\text { Bonne Aventure } \\
\text { (4 fields) }\end{array}$ & Victoria & P1-P2 & Aristotle & 12 & 2 & 10 \\
\hline Penal (2 fields) & St. Patrick & BA1-BA4 & Aristotle, Paladin & 25 & 3 & 22 \\
\hline
\end{tabular}


storage and as conidial suspensions in $50 \%$ glycerol at $-70^{\circ} \mathrm{C}$ for long-term storage.

In vitro bioassay. To test the sensitivity of isolates to benomyl (Benlate 50\% WP; Du Pont de Nemours and Company), PDA media were amended with the active ingredient (a.i.) at $0,0.1,1.0,10.0$, and $100.0 \mu \mathrm{g} / \mathrm{ml}$. Stock solutions of the fungicide were prepared in acetone (Zhang et al. 2010). The $10 \mu \mathrm{g} / \mathrm{ml}$ concentration of benomyl was used as the discriminatory dose at which sensitive or resistant isolates were identified (Peres et al. 2004; Wong et al. 2008; Young et al. 2010). Four replicates of each fungicide concentration were used for each isolate and the experiment was performed twice. Cultures were prepared by removing a $4-\mathrm{mm}^{3}$ block of mycelia from the leading edge of an actively growing 7-day-old culture and placing it mycelium-side-down in the center of fungicide-amended media. The plates were incubated at $25^{\circ} \mathrm{C}$ for 5 days and the radial diameter of each colony was measured (orthogonal measurements) for each isolate to determine the percentage of relative growth inhibited compared with the growth on nonamended media. Mean values were used in subsequent analyses because values did not differ significantly between experiments. The $\mathrm{EC}_{50}$ on fungicideamended media was calculated for isolates based on in vitro bioassays. Linear regression analysis of the percentage of growth inhibition (mycelia growth of the control versus the $\log _{10}$ of the fungicide concentration) was obtained (MINITAB v.17) for isolates according to location.

Sequence analysis of $\beta$-tubulin 2 gene. The $\beta$-tubulin 2 gene from 20 randomly selected representative $C$. truncatum isolates showing the resistant phenotype was sequenced to identify point mutations leading to amino acid substitutions that are associated with benomyl resistance. The $\beta$-tubulin 2 gene of three $C$. gloeosporioides sensu lato isolates that were sensitive to benomyl at $10.0 \mu \mathrm{g} / \mathrm{ml}(\mathrm{Cgsl}$ isolate 1 to 3 ) were also sequenced for comparison with the resistant C. truncatum isolates. Fresh mycelium was harvested from cultures grown in potato dextrose broth and used in genomic DNA extraction using the cetyltrimethylammonium bromide extraction method. Polymerase chain reaction (PCR) amplification was carried out in separate experiments using the primer pairs developed by Wong et al. (2008), Peres et al. (2004), and Ma et al. (2003). For a single $25 \mu \mathrm{l}$ reaction, PCR components (Invitrogen by Life Technologies Co.) included $1 \times$ PCR buffer, $1.5 \mathrm{mM} \mathrm{MgCl}_{2}, 0.2 \mathrm{mM}$ dNTP, $2.5 \mathrm{U}$ of Taq DNA Polymerase, and $50 \mathrm{pmol}$ of each primer (Integrated DNA Technologies). PCR amplification thermal conditions consisted of an initial denaturation of $5 \mathrm{~min}$ at $94^{\circ} \mathrm{C}$; followed by 35 cycles of $1 \mathrm{~min}$ at $94^{\circ} \mathrm{C}, 1 \mathrm{~min}$ at $55^{\circ} \mathrm{C}$, and $1 \mathrm{~min}$ at $72^{\circ} \mathrm{C}$; with a final extension of $5 \mathrm{~min}$ at $72^{\circ} \mathrm{C}$. PCR products were sequenced directly and in both directions (Amplicon Express). Nucleotide sequences were aligned and edited using Bioedit sequence alignment editor software, version 7.2.5 (http://www.mbio.ncsu.edu/bioedit/page2. html). Nucleotide sequences were then translated and the amino acid sequences were manually edited to a common length. Ten representative $C$. truncatum sequences were included in the final dataset as the sequences were invariable. Sequences of both benomylresistant and sensitive Colletotrichum isolates (Wong et al. 2008; Young et al. 2010) were used for comparison with sequences obtained in this study.

Genetic analysis of sensitive and resistant isolates. Genetic analysis of $\beta$-tubulin 2 gene sequences was conducted to determine whether benomyl-sensitive Colletotrichum isolates were genetically similar enough to form a separate cluster from resistant isolates. Sequences of the $\beta$-tubulin 2 gene were subjected to multiple sequence alignment using the online version of MAFFT (version 6; http://mafft.cbrc.jp/alignment/server/). Genetic analyses were conducted in MEGA6 (Tamura et al. 2013) and relationships were inferred using the maximum-likelihood method based on the general time-reversible model using a $\gamma$ distribution with invariant sites (GTR+G+I; best-fit model based on Bayesian Information Criterion, Akaike Information Criterion, and maximum-likelihood scores). The unrooted topological tree with the highest log likelihood was generated from boot strapping 1,000 replicates (Felsenstein 1985). The analysis included 31 nucleotide sequences with 444 positions in the final dataset; all positions containing gaps and missing data were eliminated.

\section{Results}

In vitro bioassay. Eighty-seven $C$. truncatum isolates were obtained from symptomatic bell pepper collected from 17 fields across Trinidad (Table 1) and screened for resistance to benomyl at the discriminatory concentration of $10 \mu \mathrm{g} / \mathrm{ml}$. All isolates were found to be highly resistant to this fungicide. Percent relative growth of resistant isolates was similar across all concentrations. The $\mathrm{EC}_{50}$ values for benomyl-resistant $C$. truncatum isolates were calculated to be greater than $1,000.0 \mu \mathrm{g} / \mathrm{ml}$. In comparison, $C$. gloeosporioides sensu lato isolates $(n=10)$ were sensitive to benomyl at the discriminatory dose of $10.0 \mu \mathrm{g} / \mathrm{ml}$, with $100 \%$ growth inhibition (Fig. 2). The percent relative growth of $C$. truncatum isolates according to geographical region is shown in Table 2 . At a benomyl concentration of $10 \mu \mathrm{g} / \mathrm{ml}$, relative growth of $C$. truncatum isolates was inhibited by only $4.6 \%$ for isolates collected in South Trinidad compared with $4.4 \%$ of isolates collected in North Trinidad. More specifically, in the north, isolates collected from fields located in Maloney and Macoya had a growth inhibition of 5.8\% compared with Aranguez isolates, which exhibited $2.8 \%$ growth inhibition. Calculated $\mathrm{EC}_{50}$ values were significantly higher $(P \leq 0.05)$ for isolates collected in the south compared with those collected in the north (Table 2). For fields located in the north, $\mathrm{EC}_{50}$ values of $C$. truncatum isolates were significantly higher $(P \leq 0.05)$ for fields located in Aranguez compared with those located in Maloney and Macoya. In the south, $C$. truncatum isolates collected from Bonne Aventure had significantly higher $\mathrm{EC}_{50}$ values $(P \leq 0.05)$ compared with isolates collected from fields located in Penal.
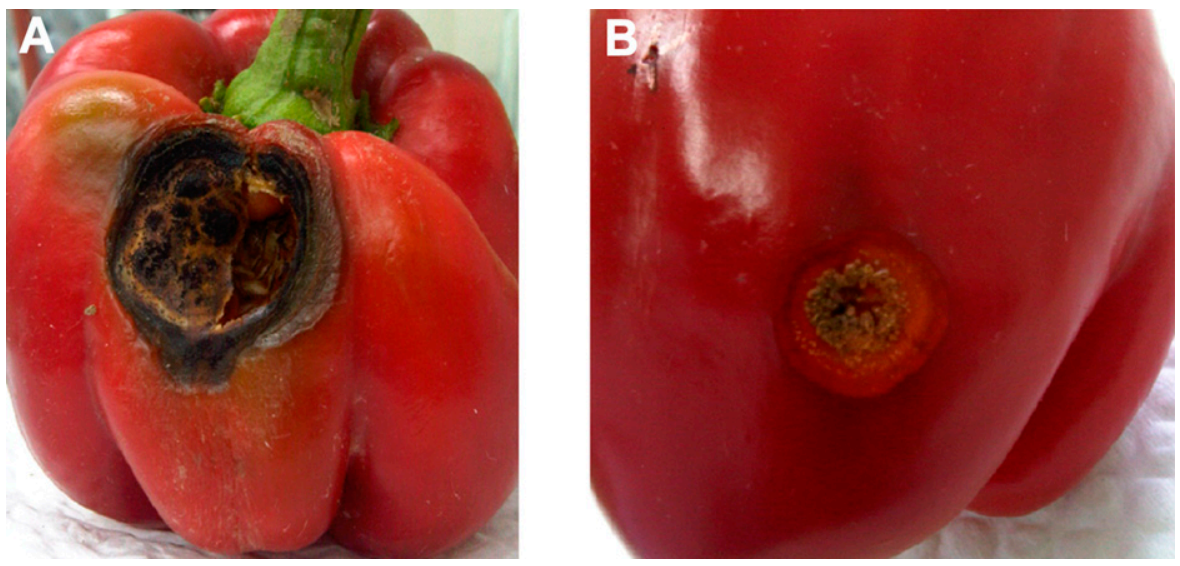

Fig. 1. Symptoms of anthracnose infection in bell pepper caused by A, Colletotrichum truncatum and B, C. gloeosporioides sensu lato. 
Sequence analysis of $\boldsymbol{\beta}$-tubulin 2 gene. Nucleotide sequences of the $\beta$-tubulin 2 gene were targeted using primers developed by Wong et al. (2008). A single amplicon of expected band size (500 bp) was obtained for all DNA samples. PCR amplification resulted in amplification of a target nucleotide sequence which, when translated, corresponded to amino acids 163 to 303 . Amino acids 198 and 200 typically are associated with benzimidazole resistance in phytopathogenic fungi. The other primer pairs developed by Ma et al. (2003) and Peres et al. (2004) were unsuccessful in amplifying the $\beta$-tubulin 2 gene.

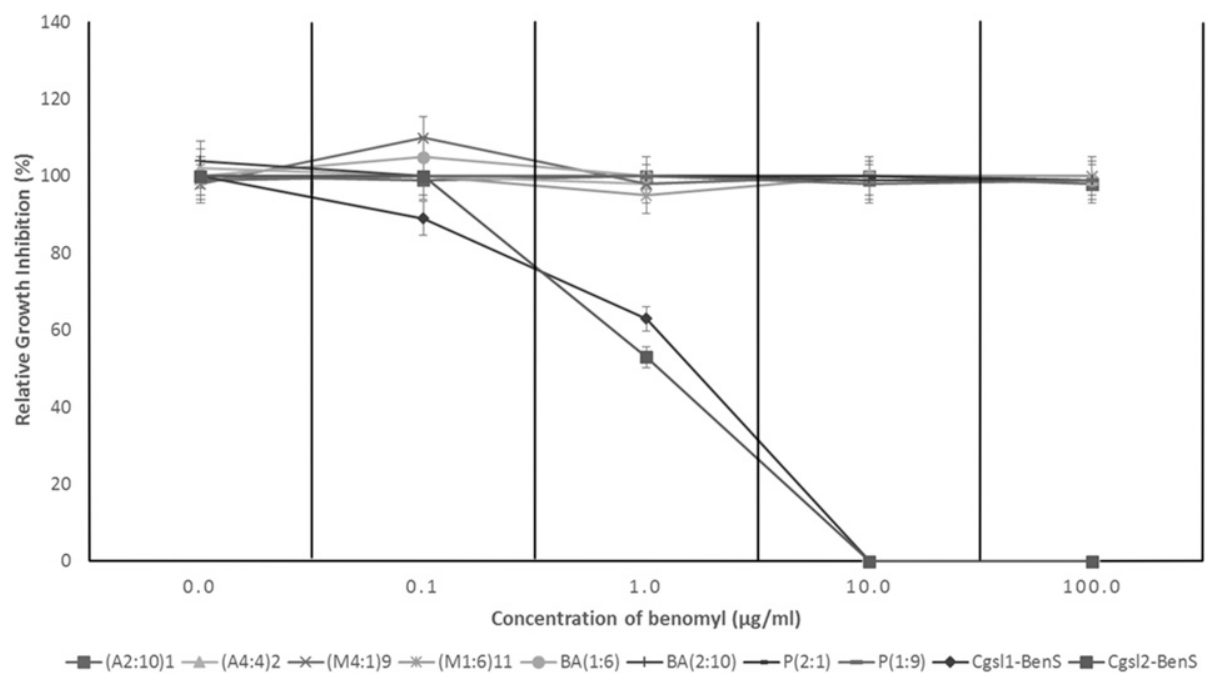

Fig. 2. Percent relative growth of representative benomyl-resistant Colletotrichum truncatum isolates from bell pepper compared with growth of benomyl sensitive C. gloeosporioides sensu lato isolates on benomyl-amended potato dextrose agar. The five concentrations of benomyl tested were $0,0.1,1.0,10.0$, and $100.0 \mu \mathrm{g} / \mathrm{ml}$.

Table 2. Percent relative growth inhibition and $\log$ effective concentration required to achieve $50 \%$ colony growth inhibition $\left(\mathrm{EC}_{50}\right)$ values of $C$. truncatum isolates by region

\begin{tabular}{|c|c|c|c|c|c|c|c|}
\hline \multirow[b]{2}{*}{$N^{\mathrm{a}}$} & \multirow[b]{2}{*}{ Region $^{b}$} & \multicolumn{4}{|c|}{ Growth inhibition (\%) } & \multirow[b]{2}{*}{$\log \mathrm{EC}_{50}$} & \multirow[b]{2}{*}{ Regression equation ( $R^{2}$ value $)$} \\
\hline & & $0.1 \mu \mathrm{g} / \mathrm{ml}$ & $1.0 \mu \mathrm{g} / \mathrm{ml}$ & $10.0 \mu \mathrm{g} / \mathrm{ml}$ & $100.0 \mu \mathrm{g} / \mathrm{ml}$ & & \\
\hline$\overline{10}$ & South: P & 2.49 & 0.94 & 3.78 & 13.04 & 15.53 & $y=3.448 x-3.558\left(R^{2}=0.669\right)$ \\
\hline 22 & South: BA & 9.05 & 8.14 & 6.65 & 13.06 & 41.21 & $y=1.053 x+6.593\left(R^{2}=0.246\right)$ \\
\hline 32 & South composite & 4.61 & 3.07 & 3.94 & 12.11 & 21.34 & $y=2.339 x+0.086\left(R^{2}=0.526\right)$ \\
\hline 27 & North: M1 and M2 & 8.98 & 12.3 & 17.49 & 32.59 & 7.04 & $y=7.105 x\left(R^{2}=0.736\right)$ \\
\hline 28 & North: A & 0 & 3.87 & 5.28 & 12.34 & 20.58 & $y=2.43 x\left(R^{2}=0.777\right)$ \\
\hline 55 & North composite & 8.98 & 8.09 & 11.39 & 22.46 & 9.16 & $y=6.285 x-7.551\left(R^{2}=0.767\right)$ \\
\hline
\end{tabular}

a Number of isolates.

b $\mathrm{P}=$ Penal (south, 2 fields), BA = Bonne Aventure (south, 4 fields), A = Aranguez (north, 5 fields), M1 = Maloney (north, 3 fields), and M2 = Macoya (north, 3 fields).
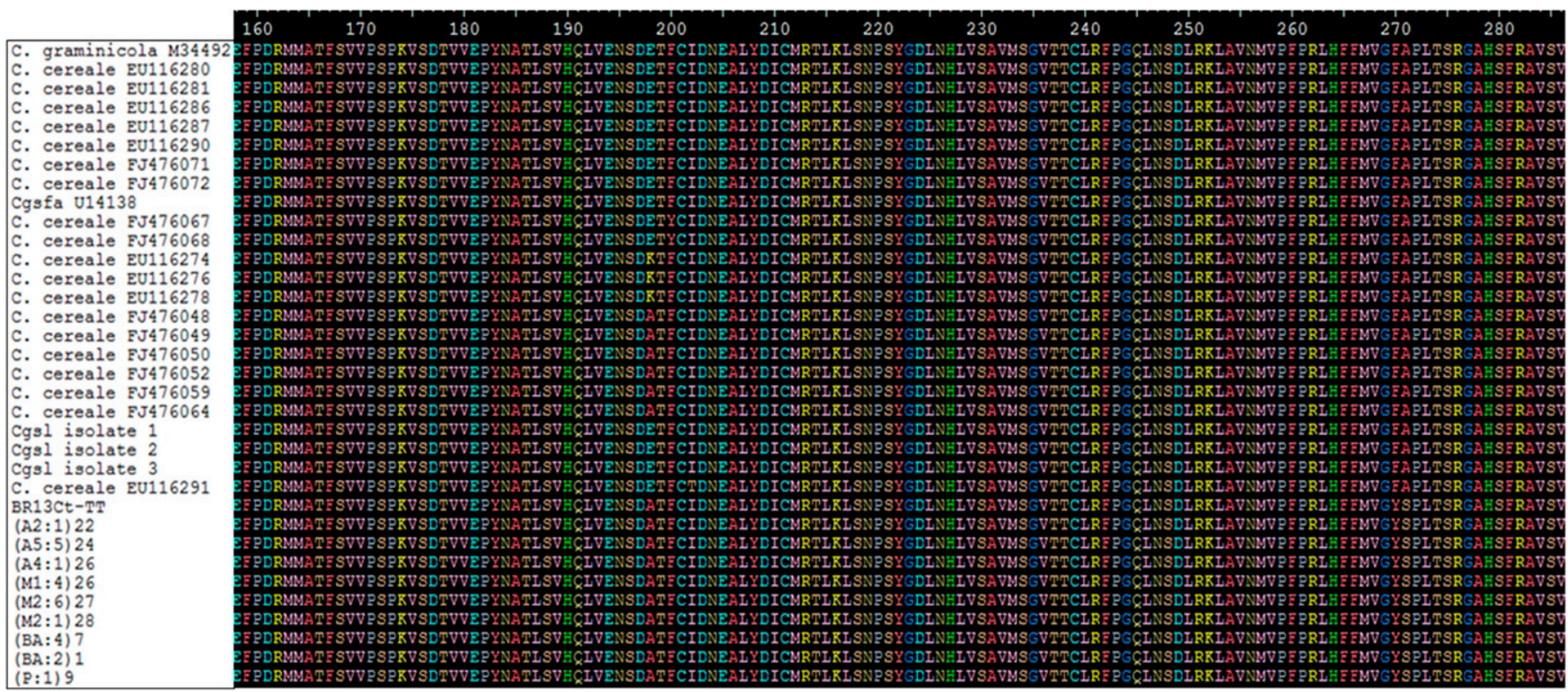

Fig. 3. Partial amino acid sequences of Colletotrichum spp. after translation of the partial $\beta$-tubulin 2 gene. 
Nucleotide sequences from representative resistant isolates from bell pepper in Trinidad were analyzed (because the sequences were identical, a representative sequence was submitted to GenBank, accession number KR029613). Based on the translation of nucleotide sequences obtained, all isolates that were classified as resistant to benomyl exhibited an amino acid change from Glu to Ala at position 198 (E198A; Fig. 3). C. truncatum isolates collected from all fields sampled had the resistant phenotype and the E198A mutation in the $\beta$-tubulin 2 gene. For comparison, sequences of benomyl-sensitive isolates mined from GenBank retained Glu at position 198, which is consistent with the original $C$. graminicola $\beta$-tubulin 2 gene sequence (M34492). Sequence comparisons indicated two additional deduced amino acid changes at nucleotide positions 359 to 361 (ATA/TTG [F270Y]) and at 362 to 364 (CGC/GCC [A271S]). Because all $C$. truncatum sequences possessed these nucleotide changes, it is likely that these may be actual genotypes and not a result of sequencing error. Sequences used in this comparison are described in Table 3.

Genetic analysis revealed that benomyl-sensitive isolates clustered separately from the resistant isolates regardless of species, with strong bootstrap support (85\%; Fig. 4). Within the resistance cluster, there was an apparent differentiation among those isolates with the F200Y, E198A, and E198K genotypes, with moderate support $(>60 \%)$ for clustering of the F200Y and E198K genotypes. C. truncatum formed a strongly supported $(97 \%)$ cluster that was separate from the other resistant genotypes due to the additional amino acid substitutions detected (Fig. 3).

\section{Discussion}

This is the first study to determine the response of $C$. truncatum isolates infecting bell pepper in Trinidad to a benzimidazole fungicide and to characterize the $\beta$-tubulin 2 gene for these isolates associated with the resistant phenotype. Fungicide use has a direct impact on pathogen populations in the field. One result is the selection of resistant populations which may persist after removal of selection by the chemical, depending on the stability and fitness of these resistant types (Lucas et al. 2015). In Trinidad, C. truncatum is the predominant causal agent of bell pepper anthracnose while $C$. gloeosporioides sensu lato isolates were detected at significantly lower frequencies. Although $C$. truncatum isolates were found to be resistant in all geographical locations sampled, there was a higher $\mathrm{EC}_{50}$ value for south-originating isolates compared with those isolates collected in the north.

Most growers experience poor management of anthracnose fruit rot in fields subjected to sustained benzimidazole fungicide use. The findings of this study suggest that, although control of C. gloeosporioides sensu lato isolates using benzimidazoles proved to be effective at reducing the size of this pathogen population, the C. truncatum population appeared to increase over a 4-year period. This underlines the importance of accurate identification of Colletotrichum spp. associated with anthracnose and routine monitoring of these isolates for development of fungicide resistance. This work has revealed the emergence of benzimidazole fungicide resistance in Trinidad bell pepper populations of $C$. truncatum and it is proposed that this be taken into consideration in the development of any integrated anthracnose fruit rot management program.

Torres-Calzada et al. (2015) reported that 20 C. truncatum isolates from papaya, pepper, and physic nut were resistant to thiabendazole in Mexico. The authors proposed that their findings may be explained by the continuous, year-round production of pepper and papaya with a constant use of fungicides, which results in sustained exposure of these isolates to benzimidazole fungicides. Similarly, in Trinidad, cocultivation of or rotation of pepper and papaya is common.

Table 3. Reference sequences used to compare amino acid substitutions at positions 198 and 200 for Colletotrichum spp.

\begin{tabular}{|c|c|c|c|c|c|}
\hline GenBank Accession Number & Isolate ID & Species & Benzimidazole phenotype & Benzimidazole genotype & Reference \\
\hline FJ476048 & BO 69 & Colletotrichum cereale & Resistant & E198A & Young et al. 2010 \\
\hline FJ476049 & BO 637 & C. cereal & Resistant & E198A & Young et al. 2010 \\
\hline FJ476050 & BO 123 & C. cereal & Resistant & E198A & Young et al. 2010 \\
\hline FJ476052 & FL B3-1 & C. cereal & Resistant & E198A & Young et al. 2010 \\
\hline FJ476059 & OO 7 E5-1 & C. cereal & Resistant & E198A & Young et al. 2010 \\
\hline FJ476064 & OW 15 14b-1 & C. cereal & Resistant & E198A & Young et al. 2010 \\
\hline FJ476067 & OW $161 \mathrm{C}$ & C. cereal & Resistant & F200Y & Young et al. 2010 \\
\hline FJ416068 & OW 19 14B & C. cereal & Resistant & F200Y & Young et al. 2010 \\
\hline FJ476071 & TF $1 \mathrm{~A}$ & C. cereal & Sensitive & E198 & Young et al. 2010 \\
\hline FJ476072 & TF $1 \mathrm{C}$ & C. cereal & Sensitive & E198 & Young et al. 2010 \\
\hline EU116274 & AHCC-10.43 & C. cereal & Resistant & E198K & Wong et al. 2008 \\
\hline EU116276 & ANCG-17.20 & C. cereal & Resistant & E198K & Wong et al. 2008 \\
\hline EU116278 & ANCG-17.30 & C. cereal & Resistant & E198K & Wong et al. 2008 \\
\hline EU116291 & TCGC-5.35 & C. cereal & Sensitive & E198K & Wong et al. 2008 \\
\hline EU116280 & DICC-8.62 & C. cereal & Sensitive & E198 & Wong et al. 2008 \\
\hline EU116281 & DICC-8.65 & C. cereal & Sensitive & E198 & Wong et al. 2008 \\
\hline EU116286 & SCCC-6.18 & C. cereal & Sensitive & E198 & Wong et al. 2008 \\
\hline EU116287 & SCCC-6.19 & C. cereal & Sensitive & E198 & Wong et al. 2008 \\
\hline EU116290 & TCGC-5.31 & C. cereal & Sensitive & E198 & Wong et al. 2008 \\
\hline U14138 & TUB 2 & $\begin{array}{l}\text { C. gloeosporioides } \\
\text { subsp. aeschynomene }\end{array}$ & Sensitive & E198 & GenBank \\
\hline M34492 & TUB 2 & C. graminicola & Sensitive & E198 & GenBank \\
\hline \multirow[t]{12}{*}{ KR029613 } & BR13Ct-TT & C. truncatum & Resistant & E198A & This study \\
\hline & $(\mathrm{A} 2: 1) 22$ & C. truncatum & Resistant & E198A & This study \\
\hline & $(\mathrm{A} 5: 5) 24$ & C. truncatum & Resistant & E198A & This study \\
\hline & $(\mathrm{A} 4: 1) 26$ & C. truncatum & Resistant & E198A & This study \\
\hline & (M1:4)26 & C. truncatum & Resistant & E198A & This study \\
\hline & (M2:6)27 & C. truncatum & Resistant & E198A & This study \\
\hline & $(\mathrm{M} 2: 1) 28$ & C. truncatum & Resistant & E198A & This study \\
\hline & $\mathrm{P}(2: 9)$ & C. truncatum & Resistant & E198A & This study \\
\hline & $\mathrm{P}(1: 3)$ & C. truncatum & Resistant & E198A & This study \\
\hline & $\mathrm{BA}(4: 7)$ & C. truncatum & Resistant & E198A & This study \\
\hline & $\mathrm{P}(1: 9)$ & C. truncatum & Resistant & E198A & This study \\
\hline & $\mathrm{BA}(2: 1)$ & C. truncatum & Resistant & E198A & This study \\
\hline
\end{tabular}


C. truncatum is an important pathogen that causes anthracnose of papaya in both countries (Rampersad et al. 2013). Torres-Calzada et al. (2015) found additional amino acid substitutions for $C$. truncatum. In this study, there were two additional amino acid substitutions detected for $C$. truncatum infecting bell pepper in Trinidad. Characterization of these additional genotypes should be carried out to determine whether they may be associated with the benzimidazoleresistant phenotype or whether these represent sequence variations that are species specific for $C$. truncatum.

Benomyl-resistant $C$. truncatum isolates from bell pepper in Trinidad had the E198A genotype similar to other resistant Colletotrichum spp. (Peres et al. 2004). Loss of field performance in most phytopathogenic fungi, however, has been associated with six target site mutations at codons 6, 50, 167, 198, 200, and 240 (Lucas et al. 2015), with the most common and significant mutations occurring at codons 198 and 200. It is possible that the results of this study may not be reflective of the entire $C$. truncatum population in bell pepper fields in Trinidad, perhaps due to sampling size. Benomylsensitive $C$. truncatum isolates may still exist, albeit in very low frequencies in the field (much lower than can be detected at the time of this study), or there may be less frequent genotypes associated with resistant $C$. truncatum isolates, with mutations outside of the amino acid substitutions identified in this study.

Genetic analysis conducted in this study indicated that benzimidazoleresistant Colletotrichum isolates clustered separately from benzimidazolesensitive isolates based on nucleotide sequences of the $\beta$-tubulin 2 gene. Hu et al. (2015) performed multigene analysis using the calmodulin, glyceraldehyde-3-phosphate dehydrogenase, and $\beta$-tubulin 2 gene sequences and found, similarly, that thiophanate-methylresistant $C$. siamense isolates were differentiated from sensitive ones.

Single-site fungicides are often potent and, therefore, facilitate disease control at very low dose rates. Hence, following fungicide application, the majority of individuals in the pathogen population are inhibited from completing their life cycle, resulting in selection for resistant individuals. This appears to be the case for $C$. truncatum populations in bell pepper fields in Trinidad. It was demonstrated for Septoria tritici isolates (during 1973 to 1984) that the E198A substitution was maintained in resistant isolates at high frequency and that benzimidazole resistance remained stable, in some areas, 10 years or more after benzimidazole use was discontinued, confirming the stability of the trait and lack of fitness costs (Lucas et al. 2015). These findings support the need to routinely monitor C. truncatum populations in bell pepper after benzimidazole use has been withdrawn in affected fields.

Failure to respond to benzimidazole fungicides is a result of reduced binding affinity of the benzimidazoles to the target binding site of the $\beta$-tubulin 2 protein (Hollomon et al. 1998; Oakley 2004). Other possible resistance mechanisms have also been reported. In some fungi such as $C$. acutatum which are intrinsically less sensitive to benzimidazoles, benomyl resistance is due to enhanced expression of the CaTUB1 gene, which is controlled by CaBEN1 (Nakaune and Nakano 2007). These alterations, while conferring resistance to benzimidazole fungicides, do not significantly affect correct functioning of the $\beta$-tubulin protein and fitness of resistant isolates. Genotyping of field-resistant isolates, as conducted in this study, is important to characterizing fungicide resistance.

It is possible that species selection was compounded by other factors; for example, cultural practices such as differences in crop rotation or field sanitation practices, differences in the frequency of fungicide application, factors that affect host plant susceptibility to infection such as fertilization regimen which would affect the need for chemical use, and coinfection with other fungal, bacterial, and viral pathogens. In the absence of any empirical data to identify what factors may affect selection of one Colletotrichum sp. over another, it is proposed that selection of a $C$. truncatum-resistant population has occurred in bell pepper fields in Trinidad as a result of continuous benzimidazole fungicide use. There is an immediate need for more fundamental knowledge of $C$. truncatum biology to inform estimates of resistance risk.

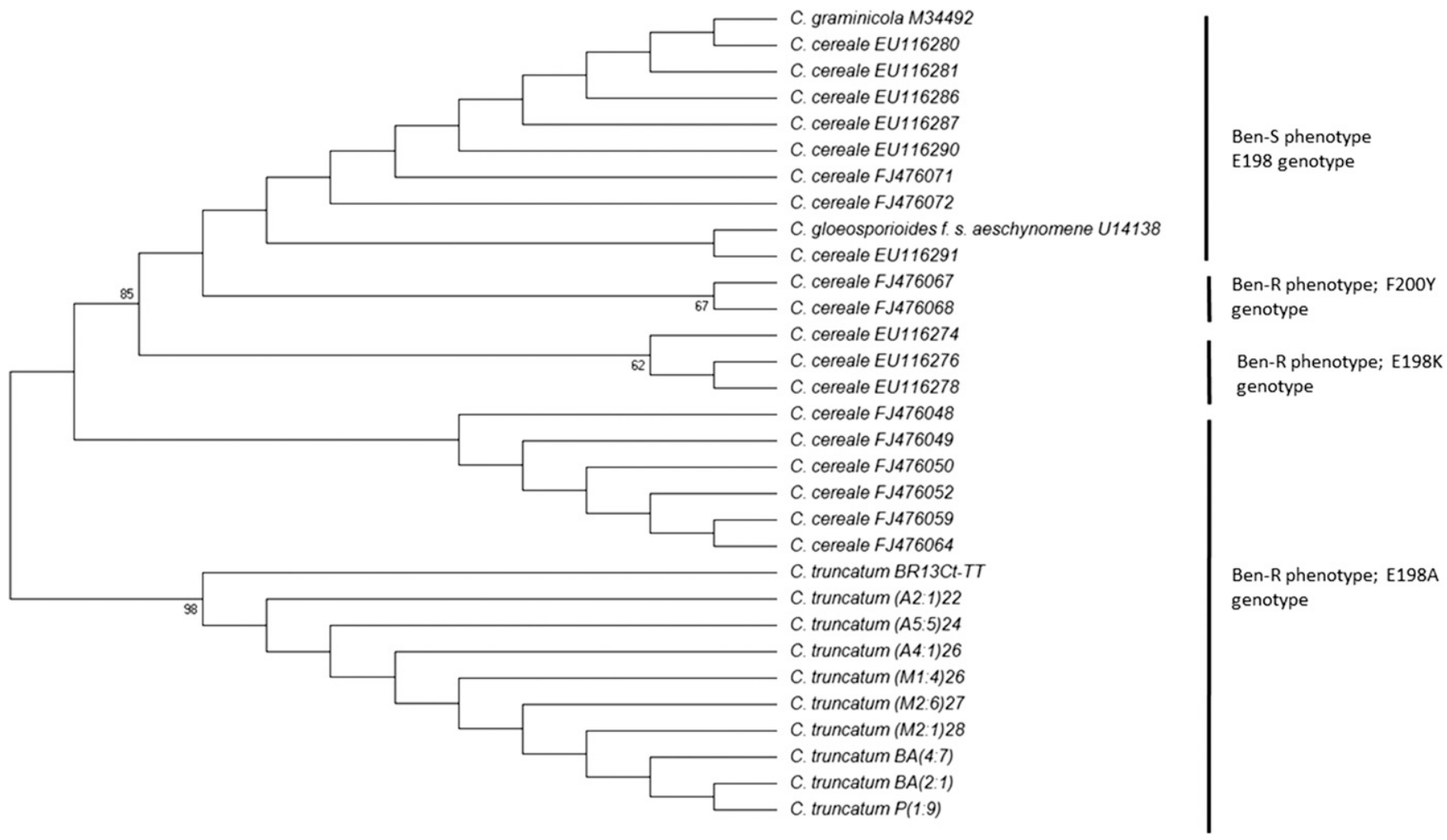

Fig. 4. Maximum-likelihood (ML) unrooted topological tree of benomyl-sensitive and benomyl-resistant Colletotrichum isolates. Ten representative Colletotrichum truncatum isolates infecting bell pepper in Trinidad were included in the analysis. The ML tree with the highest log likelihood is shown and was generated from boot strapping 1,000 replicates and using the best-fit model $(G T R+G+I)$. The analysis involved 31 nucleotide sequences. All positions containing gaps and missing data were eliminated. There were 444 positions in the final dataset. 


\section{Acknowledgments}

This work was funded, in part, by The University of the West Indies Campus Research and Publications Fund, grant number CRP.3.NOV11.8.

\section{Literature Cited}

AVRDC. 1991. The World Vegetable Center Factsheet: Pepper Diseases-A Field Guide. AVRDC Publ. No. 91-374. Asian Vegetable Research and Development Center, Shanhua, Tainan, Taiwan, ROC.

AVRDC. 2004. The World Vegetable Center Factsheet: Pepper DiseasesAnthracnose Colletotrichum gloeosporioides, C. capsici, C. acutatum, and C. coccodes. AVRDC Publ. No. 04-574. Asian Vegetable Research and Development Center, Shanhua, Tainan, Taiwan, ROC.

Chung, W., Ishii, H., Nishimura, K., Fukaya, M., Yano, K., and Kajitani, Y. 2006. Fungicide sensitivity and phylogenetic relationship of anthracnose fungi isolated from various fruit crops in Japan. Plant Dis. 90:506-512.

Conn, K., ed. 2006. Pepper and Eggplant Disease Guide-A Practical Guide for Seedsmen, Growers and Agricultural Advisors. Online publication. Seminis, Oxnard, CA. http://seminisus.s3.amazonaws.com/wp-content/uploads/2014/ 09/SEM-12095_PepperDiseases_8p5x11_072313.pdf

Damm, U., Woudenberg, J. H. C., Cannon, P. F., and Crous, P. W. 2009. Colletotrichum species with curved conidia from herbaceous hosts. Fungal Divers. 39:45-87.

Davidse, L. C. 1986. Benzimidazole fungicides: Mechanism of action and biological impact. Annu. Rev. Phytopathol. 24:43-65.

Davidson, R. M., Hanson, L. E., Franc, G. D., and Panella, L. 2006. Analysis of $\beta$-tubulin gene fragments from benzimidazole-sensitive and -tolerant Cercospora beticola. J. Phytopathol. 154:321-328.

Felsenstein, J. 1985. Confidence limits on phylogenies: An approach using the bootstrap. Evolution 39:783-791.

FRAC. 2014. Benzimidazoles-Site of action and mechanism(s) of resistance. Online publication. Fungicide Resistance Action Committee. http://www.frac. info/expert-fora/benzimidazoles/soa-and-mechanism(s)-of-resistance.

Harp, T., Kuhn, P., Roberts, P. D., and Pernezny, K. L. 2014. Management and cross-infectivity potential of Colletotrichum acutatum causing anthracnose on bell pepper in Florida. Phytoparasitica 42:31-39.

Harp, T. L., Pernezny, K., Lewis Ivey, M. L., Miller, S. A., Kuhn, P. J., and Datnoff, L. 2008. The etiology of recent pepper anthracnose outbreaks in Florida. Crop Prot. 27:1380-1384.

Hollomon, D. W., Butters, J. A., Barker, H., and Hall, L. 1998. Fungal beta-tubulin, expressed as a fusion protein, binds benzimidazole and phenylcarbamate fungicides. Antimicrob. Agents Chemother. 42:171-173.

Hu, M.-J., Grabke, A., Dowling, M. E., Holstein, H. J., and Schnabel, G. 2015. Resistance in Colletotrichum siamense from peach and blueberry to thiophanatemethyl and azoxystrobin. Plant Dis. 99:806-814.

Jung, M. K., and Oakley, B. R. 1990. Identification of an amino acid substitution in the benA, $\beta$-tubulin gene of Aspergillus nidulans that confers thiabendazole resistance and benomyl supersensitivity. Cell Motil. Cytoskeleton 17:87-94.

Koenraadt, H., Somerville, S. C., and Jones, A. L. 1992. Characterization of mutations in the beta-tubulin gene of benomyl-resistant field strains of Venturia inaequalis and other plant-pathogenic fungi. Phytopathology 82:1348-1354.

Lewis Ivey, M. L., Nava-Diaz, C., and Miller, S. A. 2004. Identification and management of Colletotrichum acutatum on immature bell peppers. Plant Dis. 88:1198-1204.

Liu, S., Duan, Y., Ge, C., Chen, C., and Zhou, M. 2013. Functional analysis of the beta (2) tubulin gene of Fusarium graminearum and the beta-tubulin gene of Botrytis cinerea by homologous replacement. Pest Manage. Sci. 69: 582-588.

Liu, X., Yin, Y., Wu, J., and Ma, Z. 2010. Identification and characterization of carbendazim-resistant isolates of Gibberella zeae. Plant Dis. 94:1137-1142.

Lucas, J. A., Hawkins, N. J., and Fraaije, B. A. 2015. Chapter 2-The evolution of fungicide resistance. Pages 29-92 in: Advances in Applied Microbiology, Vol. 90. S. Sariaslani and G. M. Gadd, eds. Academic Press, London.

Ma, Z., and Michailides, T. J. 2005. Advances in understanding molecular mechanisms of fungicide resistance and molecular detection of resistant genotypes in phytopathogenic fungi. Crop Prot. 24:853-863.

Ma, Z., Yoshimura, M. A., and Michailides, T. J. 2003. Identification and characterization of benzimidazole resistance in Monilinia fructicola from stone fruit orchards in California. Appl. Environ. Microbiol. 69:7145-7152.

Maymon, M., Zveibil, A., Pivonia, S., Minz, D., and Freeman, S. 2006. Identification and characterization of benomyl-resistant and -sensitive populations of Colletotrichum gloeosporioides from statice (Limonium spp.). Phytopathology 96:542-548.
Mohammed, A. 2013. Market Profile for Sweet Pepper in Trinidad \& Tobago. The Common Fund for Commodities/European Union (CFC/EU)-financed project: "Increased Production of Vegetables and Herbs through the use of Protected Agriculture (PA) in the Caribbean" being implemented by CARDI in Haiti, Jamaica and, Trinidad \& Tobago. http://www.cardi.org/cfc-pa/files/downloads/ 2013/11/Publ-22-Market-Profile-Sweet-pepper-TT-Aziz-M.pdf

Montri, P., Taylor, P. W. J., and Mongkolporn, O. 2009. Pathotypes of Colletotrichum capsici, the causal agent of chili anthracnose, in Thailand. Plant Dis. 93:17-20.

Morton, V., and Staub, T. 2008. A Short History of Fungicides. Online publication. APSnet Features. doi:10.1094/APSnetFeature-2008-0308

Nakaune, R., and Nakano, M. 2007. Benomyl resistance of Colletotrichum acutatum is caused by enhanced expression of beta-tubulin 1 gene regulated by putative leucine zipper protein CaBEN1. Fungal Genet. Biol. 44:1324-35.

Oakley, B. R. 2004. Tubulins in Aspergillus nidulans. Fungal Genet. Biol. 41: 420-427.

Peres, N. A., Souza, N. L., Peever, T. L., and Timmer, L. W. 2004. Benomyl sensitivity of isolates of Colletotrichum acutatum and C. gloeosporioides from citrus. Plant Dis. 88:125-130.

Pernezny, K., Roberts, P. D., Murphy, J. F., and Goldberg, N. G. 2003. Compendium of Pepper Diseases. American Phytopathological Society, St. Paul, MN.

Pring, R. J., Nash, C., Zakaria, M., and Bailey, J. A. 1995. Infection process and host range of Colletotrichum capsici. Physiol. Mol. Plant Pathol. 46:137-152.

Ramdial, H., and Rampersad, S. N. 2014. Characterization of Colletotrichum spp. causing anthracnose of bell pepper (Capsicum annuum L.) in Trinidad. Phytoparasitica 43:37-49.

Rampersad, S. N. 2011. Molecular and phenotypic characterization of Colletotrichum species associated with anthracnose disease of papaya in Trinidad. Plant Dis. 95: 1244-1254.

Rampersad, S. N., Perez-Brito, D., Torres-Calzada, C., Tapia-Tussell, R., and Carrington, C. V. F. 2013. Genetic structure and demographic history of Colletotrichum gloeosporioides sensu lato and C. truncatum isolates from Trinidad and Mexico. BMC Evol. Biol. 13:130.

Roberts, P. D., Pernezny, K., and Kucharek, T. A. 2001. Anthracnose caused by Colletotrichum in pepper. University of Florida/Institute of Food and Agricultural Sciences IFAS Ext. Publ. No. PP-178.

Schmidt, L. S., Ghosoph, J. M., Margosan, D. A., and Smilanick, J. L. 2006. Mutation at $\beta$-tubulin codon 200 indicated thiabendazole resistance in Penicillium digitatum collected from California citrus packing houses. Plant Dis. 90:765-770.

Sharma, P. N., Kaur, M., Sharma, O. P., Sharma, P., and Pathania, A. 2005. Morphological, pathological and molecular variability in Colletotrichum capsici, the cause of fruit rot of chilies in the subtropical region of northwestern India. J. Phytopathol. 153:232-237.

Smith, C. M. 1988. History of benzimidazole use and resistance. Pages 23-24 in: Fungicide Resistance in North America. C. J. Delp, ed. American Phytopathological Society, St. Paul, MN.

Steffens, J. J., Pell, E. J., and Tien, M. 1996. Mechanisms of fungicide resistance in phytopathogenic fungi. Curr. Opin. Biotechnol. 7:348-355.

Tamura, K., Stecher, G., Peterson, D., Filipski, A., and Kumar, S. 2013. MEGA6: Molecular Evolutionary Genetics Analysis version 6.0. Mol. Biol. Evol. 30: 2725-2729.

Than, P. P., Jeewon, R., Hyde, K. D., Pongsupasamit, S., Mongkolporn, O., and Taylor, P. W. J. 2008. Characterization and pathogenicity of Colletotrichum species associated with anthracnose on chili (Capsicum spp.) in Thailand. Plant Pathol. 57:562-572.

Torres-Calzada, C., Tapia-Tussell, R., Higuera-Ciapara, I., Martin-Mex, R., Nexticapan-Garcez, A., and Perez-Brito, D. 2015. Sensitivity of Colletotrichum truncatum to four fungicides and molecular characterization of thiabendazoleresistant isolates. Plant Dis. 99:1590-1595.

Wade, R. H. 2007. Microtubules: An overview. Methods Mol. Med. 137:1-16.

Wong, F. P., de la Cerda, K. A., Hernandez-Martinez, R., and Midland, S. L. 2008. Detection and characterization of benzimidazole resistance in California populations of Colletotrichum cereale. Plant Dis. 92:239-246.

Yarden, O., and Katan, T. 1993. Mutations leading to substitutions at amino acids 198 and 200 of beta-tubulin that correlate with benomyl-resistance phenotypes of field strains of Botrytis cinerea. Phytopathology 83:1478-1483.

Young, J. R., Tomaso-Peterson, M., de la Cerda, K. A., and Wong, F. P. 2010. Two mutations in $\beta$-tubulin 2 gene associated with thiophanate-methyl resistance in Colletotrichum cereal isolates from creeping bentgrass in Mississippi and Alabama. Plant Dis. 94:207-212.

Zhang, C. Q., Liu, Y. H., and Zhu, N. 2010. Detection and characterization of benzimidazole resistance of Botrytis cinerea in greenhouse vegetables. Eur. J. Plant Pathol. 126:509-515. 